\title{
Indoor Nanoparticle Characterization in Construction Waste Recycling Companies over Time
}

\author{
Diana Pinto ${ }^{1}$, Alcindo Neckel ${ }^{2, *}$, Guilherme L. Dotto ${ }^{3}$ and Bashir Adelodun ${ }^{4,5}$ (D) \\ 1 Department of Civil and Environmental, Universidad de la Costa, CUC, Barranquilla 080002, Colombia; \\ dpinto3@cuc.edu.co \\ 2 Faculdade Meridional, IMED, Passo Fundo 99070-220, Brazil \\ 3 Chemical Engineering Department, Federal University of Santa Maria UFSM, Santa Maria 97105-900, Brazil; \\ guilherme_dotto@yahoo.com.br \\ 4 Department of Agricultural and Biosystems Engineering, University of Ilorin, Ilorin 240103, Nigeria; \\ adelodun.b@unilorin.edu.ng \\ 5 Department of Agricultural Civil Engineering, Kyungpook National University, Daegu 41566, Korea \\ * Correspondence: alcindo.neckel@imed.edu.br
}

Citation: Pinto, D.; Neckel, A.; Dotto G.L.; Adelodun, B. Indoor Nanoparticle Characterization in Construction Waste Recycling Companies over Time. Sustainability 2021, 13, 14071. https://doi.org/ $10.3390 /$ su132414071

Academic Editors: Edoardo Bocci and Marc A. Rosen

Received: 17 November 2021 Accepted: 16 December 2021 Published: 20 December 2021

Publisher's Note: MDPI stays neutra with regard to jurisdictional claims in published maps and institutional affiliations.

Copyright: (c) 2021 by the authors. Licensee MDPI, Basel, Switzerland. This article is an open access article distributed under the terms and conditions of the Creative Commons Attribution (CC BY) license (https:// creativecommons.org/licenses/by/ $4.0 /)$.

\begin{abstract}
Building activity is a significant source of atmospheric contamination by ultrafine dust Cognizant of this fact, those active in the use and recycling of construction materials must be aware of the risks associated with exposure to nanoparticles (NPs) and ultra-fine particles (UFPs), as well as the associated health impacts. This work analyzed NPs and UFPs generated in a small building-material recycling company using high-resolution electron microscopes and X-ray Diffraction. A self-made passive sampler (LSPS) that can obtain particulate samples without physical and morphological changes, especially where there is a suspension of particulate material, was used in this study. A total of 96 particulate samples, using the LSPS for three months in four seasons, were collected during the study. Thus, the dry deposition of the particles, which are considered highly harmful to human health, was found in each of the four seasons of the year. It is suggested that for future research, the toxicological evaluations of the particulates in the construction industry should be investigated through the consideration of measures to control and mitigate the health risks of workers regarding exposure to NPs and UFPs.
\end{abstract}

Keywords: air pollution; construction waste recycling; nanoparticles; human health

\section{Introduction}

The need to breathe contaminant-free air is essential for long-term health benefits. This need has been compromised, especially with the beginning of the industrial revolution, and therefore it is not only a matter of concern in countries such as China, the US, and India, as many studies point out [1-4]. Today, indeed, about $90 \%$ of the global population breathes contaminated air, causing more than seven million deaths annually worldwide [5]. Although there are some studies on the atmospheric contamination of outdoor air in areas of civil construction, there are no studies concerning indoor air in construction waste recycling companies, even though the study of atmospheric contaminants is highly relevant to indoor atmospheres [6-8]. For this reason, new assessments are necessary to provide more scientific information about the occurrence, composition, morphology, and distribution of contaminants in areas of construction material recycling which take place in indoor air, as well as the exposure of workers and populations as a result of such activity.

Currently, fast global development, population progress, and industrialized expansion have raised many ecological questions about waste administration [9-14]. Building and demolition rejects (BDR) comprise the greatest portion of solid rejects globally. Because it is associated with other activities, the efficiency of building production has not advanced much [15]. In European countries, building and demolition actions produce around $900 \mathrm{Mt}$ 
of BDR every year [16]. Construction and BDR structure can differ according to basis and locality, but passive compounds such as aggregates, concretes, mortars, and ceramics are frequently the major components $[3,17,18]$. Preceding works have also shown that these compounds are the principal constituents of BDR produced in many territories, such as in the Americas, Africa, Asia, and Europe [19-23].

While building activity is one of the main contributors to atmospheric pollution, scientific studies of the generation of ultra-fine particles (UFPs) and nanoparticles (NPs), and their liberation during construction processes, are still at an initial phase [24,25]. Current studies show that UFPs and NPs have dissimilar effects compared to dangerous $\mathrm{PM}_{1}$ particles $[7,26,27]$. This work investigates the diverse sizes of particles produced from small building recycling companies.

Despite the adoption of recycling, or at least attempts to recycle construction waste, problems are present in all parts of the world $[16,28]$. The authors of the present study understand that little is known about the subject of exposure to NPs and UPFs generated at different stages of the recycling of different construction waste materials, and it is rarely studied $[18,29]$. The study of particles, as well as of exposure to particulates produced in the activity of recycling construction material, is of great importance to the reduction of risks to the health of workers and the population around such activity [30-32]. The analysis and chemical definition of the particles generated in the activity of this study is a complex challenge due to the considerable heterogeneity of the materials in question [18,29,33-35].

Building materials can undergo substantial changes due to atmospheric contamination $[18,29,36-38]$, and could be the source of atmospheric pollutants [18,26,29]. In view of this scenario, the objective of this study is to evaluate the NPs and UFPs present during the activities of a small company that recycles construction waste for the manufacture of concrete blocks and materials for earthwork. As a result [26,29], this work will contribute to the knowledge that helps small companies to develop their activities in such a manner as to mitigate the related health risks of the people who are vulnerable to exposure to the particulates.

Construction waste recycling activities have been gaining momentum in Brazil, especially due to the financial stimulus offered by the government and by non-governmental organizations. This important activity is crucial in all countries of the world, since the tendency of people to live in cities increases every year. For the recycling of construction materials to be carried out, it is necessary to have greater governmental powers over civil construction companies so that they do not deposit their waste in landfills or use it in earthworks without proper treatment to separate the materials that contaminate the atmosphere, soils, and water, as reported by Oliveira et al. [29]. The present study explores the exposure to NPs and UFPs produced by construction waste recycling activities, with an emphasis on the human health risks as well as on the examination of the particles.

In the present study, a collaboration was made with a small recycling company from Porto Alegre city (Rio Grande do Sul State, Brazil). The steps which comprise the activity of this company are as follows: (1) The construction of buildings is most often performed manually and without personal protection equipment (Figure 1A); (2) When obtaining a full container, the construction residues are transported in trucks (Figure 1B) and open buckets (Figure 1C); which is incorrect, as these should be covered to avoid the dispersion of particulate materials; (3) When they arrive at the recycling company, the construction residues are dumped in the warehouse yards (Figure 1D), where the greatest generation of suspension of the less dense material was noted; (4) The initial recycling stage begins with crushing (Figure 1E), after which the material undergoes magnetic separation to remove the metals, followed by jigs (Figure 1F) where the materials of different densities and sizes are separated; (5) The metallic material is sent for recycling by medium-sized companies, while the materials obtained by jigs are used in the manufacture of concrete blocks (Figure 1G), which generates the second largest particulate suspension, especially of the less dense materials, such as plaster and coal-derived fly ash (used in all cement manufacturing in southern Brazil). (6) Although it is not part of the recycling process, 
LSPSs were also installed in the commercial office of the small company (Figure 1B,I), as much dust was deposited on shelves and doors.

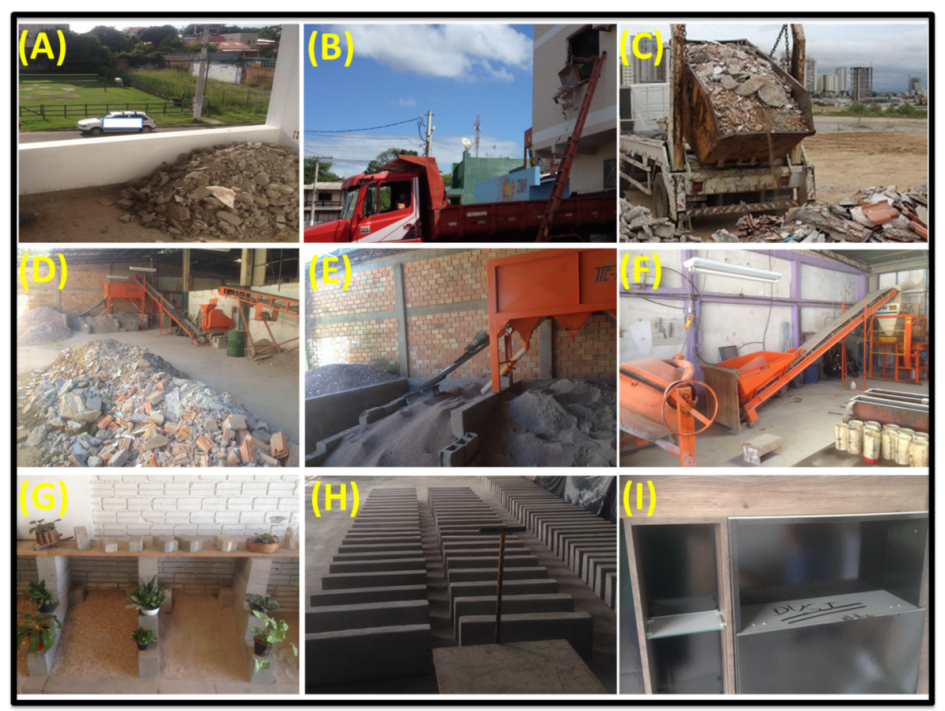

Figure 1. Summary of the main activities involved in the recycling of waste construction materials. (A) Manual deposition without personal protective equipment; (B,C) Accumulation of waste in trucks and buckets; (D) Warehouse yards/disposal and accumulation of rejects in the recycling company's yards for further treatment; (E) Grinding of rejects; (F) Separation of the materials contained in the rejects via jigs; $(\mathbf{G}, \mathbf{H})$ Examples of concrete blocks built with recycled material; (I) Illustration of an office bookcase that, although not part of the recycling process, was included in the study due to the large accumulation of sedimented particulate.

Since several studies with sensors in construction areas are highly difficult and complex [39-41], we opted for the use of a self-made passive sampler (LSPS). This sampler was used in several studies to evaluate NPs and UFPs in construction areas such as Brazil, on European islands [8,26] and in the Caribbean region [42], among many other places. The LSPS proved to be a viable sampler, especially when studying the particles that people tend to breathe, since they are fixed on the walls at an average height between 1.30 and $1.50 \mathrm{~m}$ (approximate height of the nose and mouth). In addition, the LSPS has the advantage of being different from traditional air quality equipment that only picks up particles for a few hours. In this study, LSPSs were installed in pairs in four areas of the small construction waste recycling company, to obtain a sample of the different stages of the processes involved. Since the first area was in the stage of receiving material from civil construction (Figure 1D), the second area was crushing (Figure 1E), the third area was the manufacture of concrete blocks (Figure 1G,H), and the fourth area was the accounting office (Figure 1I) - which has closed doors most of the time, as can be seen in Figure 1I-the accumulation of UFPs and NPs is intense because the cleaning routine is not effective. In addition, LSPSs were exposed for three months, thus accumulating particulates from each of the seasons of 2019. This made it possible to make a real assessment of the environment in terms of human exposure.

\section{Materials and Methods}

In each sampled LSPS (Figure 2), 150 particles were studied, making it possible to identify the type of chemical elements present in the samples, although the method does not generate quantitative data of the identified chemical elements. The method used was based on analysis by FE-SEM (Field Emission Scanning Electron Microscope), with dimensioning of $15(10-20 \mu \mathrm{m}), 30(5-10 \mu \mathrm{m}), 30(1-5 \mu \mathrm{m})$, and $30(100-1000 \mathrm{~nm})$ particles, considering the use of High-resolution transmission electron microscopy (HR-TEM), into 45 particles (less of $100 \mathrm{~nm}$ ). For this study, a copper-Cu grid of HR-TEM in the LSPS was 
used to perform the collection of ultrafine particulates. It was also added for the analysis of NPs by HR-TEM. It should be noted that it was not necessary to prepare the collected samples to perform the AM (advanced microscopy) and XRD (X-ray powder diffraction) analyses $[8,26,42]$, which in turn does not cause any change to the molecular structure of the analyzed particles [43-48].

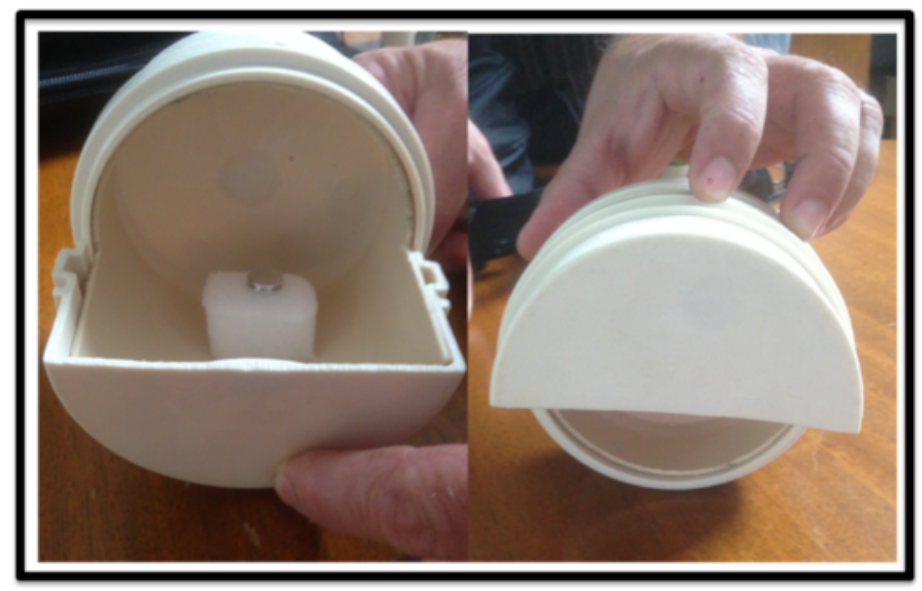

Figure 2. Illustrative photos of LSPS.

The analysis of the collected material was carried out with the X-ray diffractometer NAPLOCK and X-ray Bruker (D8 DISCOVER) to identify the mineral and amorphous phases of the sampled chemical elements [49]. Under the conditions of this study, the $\mathrm{Cu} \mathrm{K} \alpha$ monochromatic radiation, with a fixed slit of $12 \mathrm{~mm}$ and a current of $20 \mathrm{~mA}$ of $40 \mathrm{kV}$, was considered. Analysis of the samples followed a speed of $0.3^{\circ} 2 \theta / \mathrm{min}$ $\left(5-65^{\circ}\right)$. The Several ultrafine-nanoparticles (UNPs) containing mixed chemical compounds were submitted to X-ray diffraction analysis [50], as well as advanced electron beams using 200 kV of HR-TEM (High Resolution Transmission Electron Microscope). Highprecision equipment of atomic arrangement in the samples was also considered, with the fast transformation of FFT (Fourier), MBD (micro-beam diffraction), SAED (electron diffraction), STEM (scanning transmission electron microscopy), and EDS (spectroscopy dispersive X-rays), modeled in Oxford Instruments INCA 4.09 software. Consequently, the chemical elements were analyzed with a high-resolution pattern based on atomic numbers. AM/EDS reveals that PM compounds have varied geochemical formations [51]. Before the samplings were carried out, the specimen holder was completely cleaned using a plasma composed system (Gatan Model 950), which consists of a technologically advanced system, allowing that the collected samples were not contaminated by the equipment and containers used during the analysis of the particulate materials studied. The images containing the representation of chemical elements were identified by SE2 (secondary detector) in a high vacuum $\left(1 \times 10^{-9}\right.$ bar $)$; aperture accurate to $20 \mu \mathrm{m}$; a distance of $5 \mathrm{~mm}$, containing necessary magnifications $(1000 \times, 2500 \times$ and $5000 \times)$. The EDS was treated in SE2 (secondary detector), maintaining the $\mathrm{N} 2$ gas variable pressure mode ranging from 1 to $133 \mathrm{~Pa}\left(1 \mathrm{~Pa}=1 \times 10^{-5}\right.$ bar $)$, with the energy of $20 \mathrm{kV}, 8.5 \mathrm{~mm}$ of distance, and $60 \mu \mathrm{m}$ of opening [51-53]. The HR-TEM was used, containing the EDS and XRD, with $\mathrm{Cu}-\mathrm{K} \alpha$ radiation $(\lambda=1.54 \AA)$. To perform the spectroscopy, the Raman method was used to order the molecules of the analyzed particles [54,55].

\section{Results and Discussion}

Exposure to particulate matter in the construction industry raises concerns among building recycling experts and about the ecosystem in general $[56,57]$. Recycling activity in buildings is one of the major causes of atmospheric contamination [17]. Therefore, examining the generation and release of NPs and UFPs at the industrial level is essential 
for mitigating the associated health risks of exposure to particulates. It is very important to study UFPs in different sizes, especially using low-cost sensors [41], since it is necessary to apply methods such as the use of adhesives [39].

The occurrence of NP and UFP in the building recycling sites is considered as something common, in contradiction with which a wide sensitivity is required to carry out efficient regulatory procedures. The understanding of the dangers to human health produced by exposure to NPs needs to be increased, especially in construction experts, in order to decrease the health effects of NPs. To manage and improve these facts, focused control actions need to be developed and used correctly [56,57]. In the current context, it is already known that the majority of the global population will move to urban areas for financial reasons, thus increasing the need for new construction, which results in more construction waste [17]. In this way, not only should construction be better managed, and should avoid the generation of waste, but also companies that recycle construction waste must have better logistics for the transportation, storage, and recycling of the multiple compounds contained in construction waste [57].

The abundance, as well as the chemical composition of UFPs and NPs generated and suspended in the area of construction material recycling vary from one stage to another. When they arrived at the company, the construction residues were dumped (Figure 1D, warehouse yards), generating a lot of suspended particulate material. According to the results obtained in this study, this activity suspends especially amorphous particles (Figure 3A), clays (Figure 3B,C), and quartz. Considering that quartz was present as particles larger than $10 \mu \mathrm{m}$, as well as some clays, this should not be as concerning as the toxicity of the amorphous NPs and some UFP clays (Figure 3C). Regarding amorphous PFUs, a more detailed evaluation is necessary, as they have porous characteristics, which can lead to the storage of NPs containing potentially dangerous elements. Most of the time, when approaching the lens of the microscopes, such NPs have become dispersed; this fact indicates that they are not fixed to UFPs but are only sedimented and/or precipitated and can move easily.
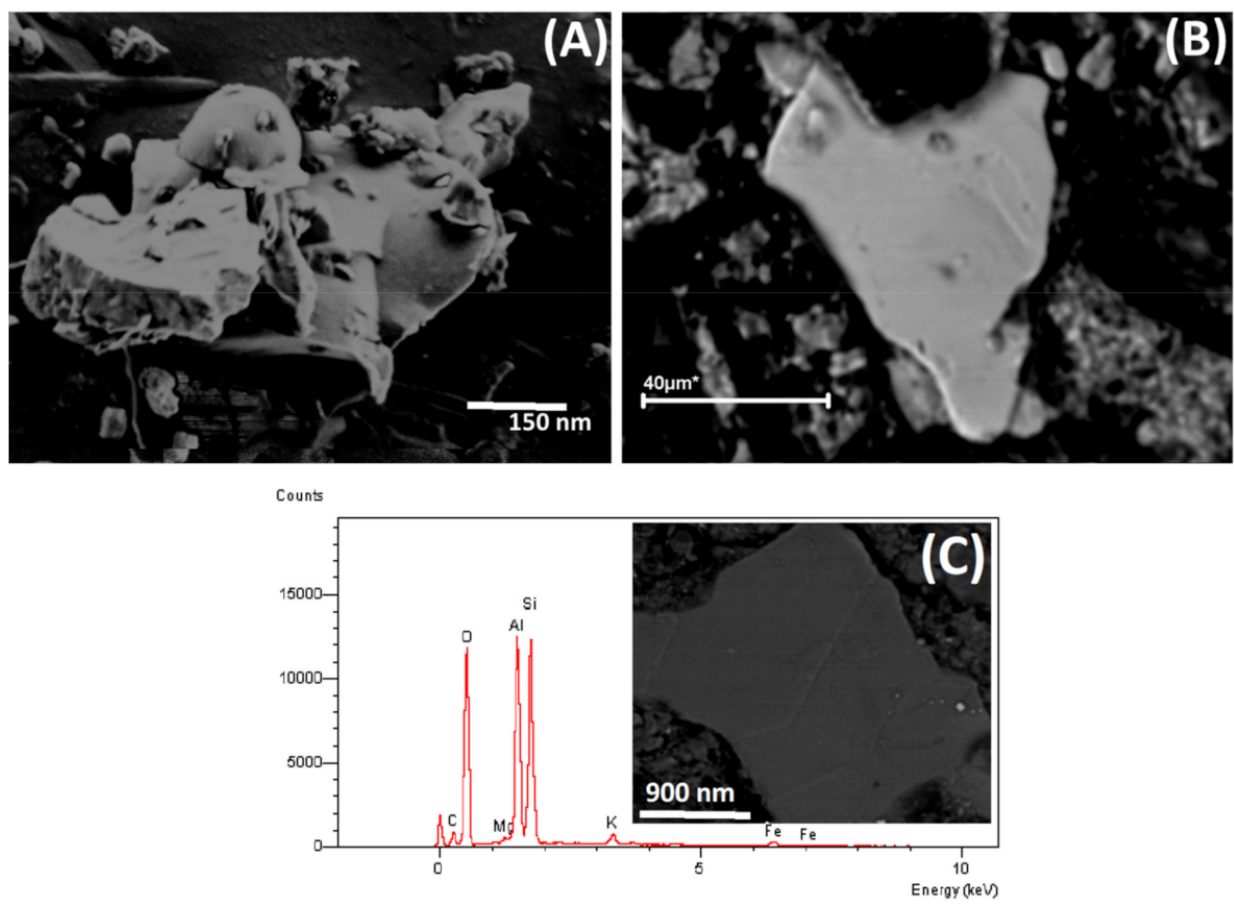

Figure 3. Principal particles and minerals detected in the warehouse yards. (A) Amorphous compounds; (B) Chlorite; (C) Illite and EDS containing trace elements.

Of all the stages of the recycling of construction material studied, crushing (Figure 1E) and jigging (Figure $1 F$ ) were the ones that visually suspended most particles. Both the 
FE-SEM stubs and the HR-TEM Cu-grids in the crushing and jigging areas were the ones that contained more particles of different sizes compared to the other recycling stages. Therefore, this step not only presents a greater risk to the health of workers and the resident population around such a company, but also presents a greater possibility for this study to evaluate the morphology, composition, and sizes of the suspended particles. As in the warehouse yards stage (Figure 1D), the crushing step (Figure 1E) and jigging (Figure 1F) also contained many amorphous particles, including carbonates such as calcite, clays such as kaolinite and muscovite, barite, gibbsite, and quartz NPs, and UFPs. However, in crushing and jigging materials it was also possible to detect heavier minerals such as goethite, hematite, magnetite, monazite, xenotime, zircon, and multiple amorphous phases containing heavy elements such as $\mathrm{Cd}, \mathrm{Cr}, \mathrm{Hg}, \mathrm{Ni}, \mathrm{Pb}$, and $\mathrm{V}$. The emission of heavy minerals such as iron hydro/oxides, zircon, and phosphates is mainly due to the strong and abundant agitation of the construction residues in the crushing and jigging stages (Figure 1E,F, respectively). This does not mean that such dense minerals remain in suspension for a long time, however, as more than $80 \%$ of the particles that contained such minerals were NPs less than $50 \mathrm{~nm}$, the risk to health, especially of workers in such stages, is greater than in the other stages, where there is no emission of such heavy minerals. It should be noted that many iron nanominerals contained potentially toxic elements such as As, Se, Sb, and W. It is suggested for further studies to carry out sampling to determine the quantity of contaminants present in the analyzed materials, which may vary from region to region, according to the abundance of the elements $\mathrm{As}, \mathrm{Se}, \mathrm{Sb}$, and $\mathrm{W}$. This corroborates the results reported for Brazilian coal-combustion fly ashes [2]. Considering that in the state of Rio Grande do Sul, where the recycling company is located, more than $90 \%$ of the manufactured cement uses coal-combustion fly ashes, it is believed that such elements, as well as rare phosphates and Fe-NPs, are derived from coal ashes. This hypothesis is based on the fact that several studies of Brazilian coals and coal by-products have detected these elements and minerals [46,50-55].

In the areas of preparation of concrete blocks (Figure 1G,H) and in the office (Figure 1I), numerous NPs of TiO2 were detected (Figure 4). However, rutile was not detected, which does not necessarily mean that it is not present in the construction residues, but does mean that it is less abundant than anatase and Ti-amorphous NPs [58,59]. In all Ti-particles studied there was an association with amorphous phases containing $\mathrm{Al}, \mathrm{Si}, \mathrm{K}, \mathrm{O}$, and $\mathrm{Mg}$, and on some occasions they were also associated with quartz and hematite. It is understood that the mixer especially produced many NP emissions. As the concrete block manufacturing area is less than 500-m away from the office, it is believed that this stage is the main source of NPs inside the office.

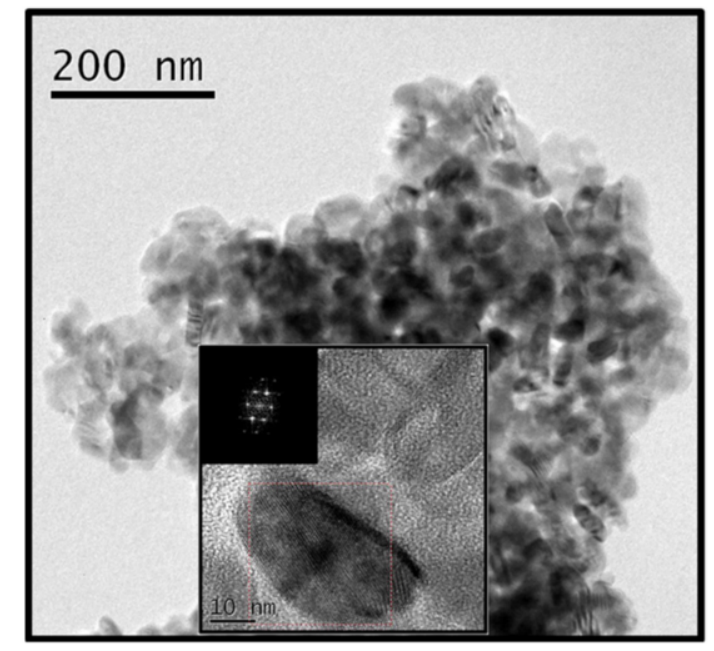

Figure 4. Nanoparticulated aggregate containing Si-Al-K-O-amorphous phases associated with anatase and Ti-NPs, with an FFT-containing magnification for an isolated anatase particle. 
During periods of rain and higher humidity, it was possible to notice a greater occurrence of gypsum and some complex hydrated phases of sulfates of $\mathrm{Ca}, \mathrm{Mg}, \mathrm{Mn}, \mathrm{Fe}$, and $\mathrm{Al}$. These phases were highly sensitive to the high vacuum of electron microscopes (Figure 5A illustrates the degradation of pickeringite during FE-SEM analyses), which indicates that, naturally, they can also be susceptible to transformations such as dehydration. As the identification through electron microscopes of such hydrated phases was complicated, the phases of larger size (e.g., gypsum, Figure 5B) were studied by magnifying glasses.

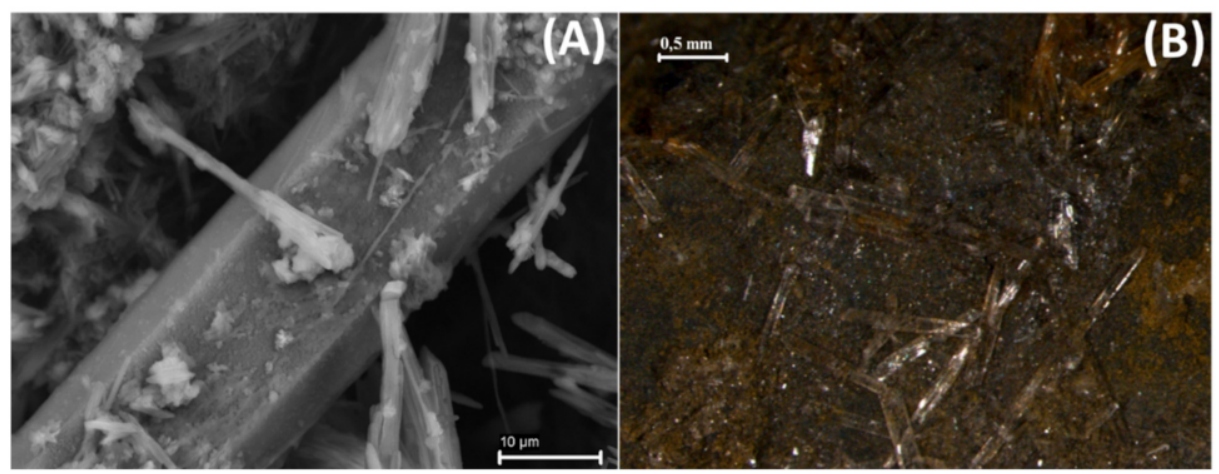

Figure 5. Hydrated phases formed with greater abundance during rainy and/or higher humidity periods. (A) Analysis of pickeringite by FE-SEM; (B) Photo of gypsum using magnifying glasses attached to a Nikon digital camera.

\section{Overview and Proposals for Future Studies}

This study was developed due to the need for methods to evaluate the deposition of NPs and UFPs over a long period of months. The data obtained in this study show especially the occupational risks associated with the recycling of construction waste. The inhalation of NPs and UFPs can increase the likelihood of respiratory diseases, in addition to generating premature deaths [26,29]. Given this scenario, it is of great importance to minimize the emission of NPs and UFPs in small recyclers. After all, if the government can help with donations and loans to buy equipment, it should not be a significant problem to help obtain glasses and masks and educate the workforce on the necessity of keeping the debris generally moist and washed at least twice a day. With such measures, occupational risk will be reduced without compromising the income or health of the families who work in this important activity, making it more sustainable [26,29].

Despite the great need to recycle residual construction material, the occupational risk in this activity increases when NPs and UFPs reach the respiratory system of workers and residents around recycling facilities. This occurs not only where the particles are produced, but also in the direction of the prevailing wind, since it can disperse and re-suspend the particles emitted in the different stages of recycling. In order to better understand the dispersion of the particulates, several factors must be evaluated, thus supporting future research work. The results of the present study signal the need for the continuous monitoring of NPs and UFPs at various stages of small-scale recycling of waste from construction materials, taking into account the major emission factors. Furthermore, there is a need for a composition analysis of the particulates over an extended period to ascertain the health implications of inhaling and ingestion of such particulates.

\section{Conclusions}

Indoor atmosphere contamination and its consequences have become a great concern to several nations due to the increase in construction activities. Studies on personal exposure to UFPs and NPs can assist in mitigating the associated health risks of exposure to indoor contaminants such as particulate materials. In this study, a systematic approach was used to assess the chemical, mineralogical, and morphological composition of NPs and UFPs produced in a construction waste recycling company. A total of 96 particulate 
samples were collected for 3 months in four seasons using LSPSs at different construction stages of a construction waste recycling company. The exposure to particulates varies according to the stages of the recycling process, with the most serious being the crushing of the residues as soon as they are received, and the subsequent mixing of the materials obtained after recycling for the production of concrete blocks.

As for the limitations of the present work, these can be referred to as the complexity of carrying out the granulometric distribution of the sampled particles. The limited scientific contribution to the variation of particulate emission in several construction materials was also a limiting factor. Therefore, additional studies are needed to mitigate the emission of NPs and UFPS, and also to monitor whether such mitigations are effective. It would also be important to carry out toxicological studies before and after each mitigation measure for the particulate material suspended in the study environment. Thus, it will be possible to improve the quality of life of the workers at the construction material recyclers, and also of the people who live around this activity.

Author Contributions: Conceptualization, D.P.; data curation, G.L.D.; formal analysis, A.N. and B.A.; funding acquisition, A.N.; investigation, D.P.; project administration, D.P.; supervision, G.L.D.; visualization, A.N. and B.A.; writing—original draft preparation, A.N.; writing—review and editing, B.A. and G.L.D. All authors have read and agreed to the published version of the manuscript.

Funding: This research received no external funding.

Institutional Review Board Statement: Not applicable.

Informed Consent Statement: Informed consent was obtained from all subjects involved in the study.

Data Availability Statement: Not applicable.

Acknowledgments: The authors gratefully acknowledge the NOAA Air Resources Laboratory (ARL) for the provision of the HYSPLIT transport and dispersion model and/or READY website (http: / / www.ready.noaa.gov, accessed on 7 October 2021) used in this publication. We also wish to thank the Center for Studies and Research on Urban Mobility (NEPMOUR/IMED). Scientific Research Institute (Instituto de Investigación Científica, IDIC) of the University of Lima and Air Centre for supporting this research. National Council for Scientific and Technological Development (CNPq) for the research productivity ball in Brazil.

Conflicts of Interest: The authors declare no conflict of interest.

\section{References}

1. Lima, B.D.; Teixeira, E.C.; Hower, J.C.; Civeira, M.S.; Ramírez, O.; Yang, C.; Oliveira, M.L.S.; Silva, L.F.O. Metal-enriched nanoparticles and black carbon: A perspective from the Brazil railway system air pollution. Geosci. Front. 2021, 12, 101129. [CrossRef]

2. Neckel, A.; Oliveira, M.L.S.; Bolaño, L.J.C.; Maculan, L.S.; Dal Moro, L.; Bodah, E.T.; Moreno-Ríos, A.L.; Bodah, B.W.; Silva, L.F.O. Biophysical matter in a marine estuary identified by the Sentinel-3B OLCI satellite and the presence of terrestrial iron (Fe) nanoparticles. Mar. Pollut. Bull. 2021, 173, 112925. [CrossRef] [PubMed]

3. Oliveira, M.L.S.; Flores, E.M.M.; Dotto, G.L.; Neckel, A.; Silva, L.F.O. Nanomineralogy of mortars and ceramics from the Forum of Caesar and Nerva (Rome, Italy): The protagonist of black crusts produced on historic buildings. J. Clean. Prod. 2021, 278, 123982. [CrossRef]

4. Trejos, E.M.; Silva, L.F.O.; Hower, J.C.; Flores, E.M.M.; González, C.M.; Pachón, J.E.; Aristizábal, B.H. Volcanic emissions and atmospheric pollution: A study of nanoparticles. Geosci. Front. 2021, 12, 746-755. [CrossRef]

5. WHO. How Air Pollution Is Destroying Our Health. 2018. Available online: https://www.who.int/air-pollution/news-andevents/how-air-pollution-is-destroying-our-health (accessed on 18 April 2021).

6. Chojer, H.; Branco, P.T.B.S.; Martins, F.G.; Alvim-Ferraz, M.C.M.; Sousa, S.I.V. Development of low-cost indoor air quality monitoring devices: Recent advancements. Sci. Total Environ. 2020, 727, 138385. [CrossRef]

7. Schneider, I.L.; Teixeira, E.C.; Dotto, G.L.; Pinto, D.; Yang, C.-X.; Silva, L.F.O. Geochemical study of submicron particulate matter (PM1) in a metropolitan area. Geosci. Front. 2020, 13, 101130. [CrossRef]

8. Silva, L.F.O.; Pinto, D.; Neckel, A.; Dotto, G.L.; Oliveira, M.L.S. The impact of air pollution on the rate of degradation of the fortress of Florianópolis Island, Brazil. Chemosphere 2020, 251, 126838. [CrossRef]

9. Dotto, G.L.; De Souza, V.C.; De Moura, J.M.; de Moura, C.M.; de Pinto, L.A.A. Influence of Drying Techniques on the Characteristics of Chitosan and the Quality of Biopolymer Films. Dry. Technol. 2011, 29, 1784-1791. [CrossRef]

10. Dotto, G.L.; Cadaval, T.R.S.; Pinto, L.A.A. Use of Spirulina platensis micro and nanoparticles for the removal synthetic dyes from aqueous solutions by biosorption. Process. Biochem. 2012, 47, 1335-1343. [CrossRef] 
11. Dotto, G.L.; Cunha, J.M.; Calgaro, C.O.; Tanabe, E.H.; Bertuol, D.A. Surface modification of chitin using ultrasound-assisted and supercritical CO2 technologies for cobalt adsorption. J. Hazard. Mater. 2015, 295, 29-36. [CrossRef]

12. Dotto, G.L.; Rodrigues, F.K.; Tanabe, E.H.; Fröhlich, R.; Bertuol, D.A.; Martins, T.R.; Foletto, E.L. Development of chitosan/bentonite hybrid composite to remove hazardous anionic and cationic dyes from colored effluents. J. Environ. Chem. Eng. 2016, 4, 3230-3239. [CrossRef]

13. Peres, E.C.; Slaviero, J.C.; Cunha, A.M.; Hosseini-Bandegharaei, A.; Dotto, G.L. Microwave synthesis of silica nanoparticles and its application for methylene blue adsorption. J. Environ. Chem. Eng. 2018, 6, 649-659. [CrossRef]

14. Oliveira, M.L.S.; Dotto, G.L.; Pinto, D.; Neckel, A.; Silva, L.F.O. Nanoparticles as vectors of other contaminants in estuarine suspended sediments: Natural and real conditions. Mar. Pollut. Bull. 2021, 168, 112429. [CrossRef]

15. Sveikauskas, L.; Rowe, S.; Mildenberger, J.; Price, J.; Young, A. Productivity Growth in Construction. J. Constr. Eng. Manag. 2016, 142, 04016045. [CrossRef]

16. European Union. Resource Efficient Use of Mixed Wastes Improving Management of Construction and Demolition Waste, 1st ed.; Final Report; Lisbon, Portugal, 2017; pp. 1-223. Available online: https://op.europa.eu/en/publication-detail/-/publication/78e42e6 c-d8a6-11e7-a506-01aa75ed71a1/language-en (accessed on 7 October 2021).

17. Oliveira, M.L.S.; Izquierdo, M.; Querol, X.; Lieberman, R.N.; Saikia, B.K.; Silva, L.F.O. Nanoparticles from construction wastes: A problem to health and the environment. J. Clean. Prod. 2019, 219, 236-243. [CrossRef]

18. Oliveira, M.L.; Neckel, A.; Pinto, D.; Maculan, L.S.; Zanchett, M.R.D.; Silva, L.F.O. Air pollutants and their degradation of a historic building in the largest metropolitan area in Latin America. Chemosphere 2021, 277, 130286. [CrossRef]

19. Sampaio, C.H.; Cazacliu, B.G.; Miltzarek, G.L.; Huchet, F.; Guen, L.L.; Petter, C.O.; Paranhos, R.; Ambrós, W.M.; Oliveira, M.L.S Stratification in air jigs of concrete/brick/gypsum particles. Constr. Build. Mater. 2016, 109, 63-72. [CrossRef]

20. Wu, Z.; Zhang, X.; Wu, M. Mitigating construction dust pollution: State of the art and the way forward. J. Clean. Prod. 2016, 112, 1658-1666. [CrossRef]

21. Gálvez-Martos, J.-L.; Styles, D.; Schoenberger, H.; Zeschmar-Lahl, B. Construction and demolition waste best management practice in Europe. Resour. Conserv. Recycl. 2018, 136, 166-178. [CrossRef]

22. Ma, Z.; Tang, Q.; Yang, D.; Ba, G. Durability Studies on the Recycled Aggregate Concrete in China over the Past Decade: A Review. Adv. Civ. Eng. 2019, 2019, 4073130. [CrossRef]

23. Wang, B.; Yan, L.; Fu, Q.; Kasal, B. A Comprehensive Review on Recycled Aggregate and Recycled Aggregate Concrete. Resour. Conserv. Recycl. 2021, 171, 105565. [CrossRef]

24. Cheriyan, D.; Choi, J.-H. A review of research on particulate matter pollution in the construction industry. J. Clean. Prod. 2020, 254, 120077. [CrossRef]

25. Curto, A.; Donaire-Gonzalez, D.; Barrera-Gómez, J.; Marshall, J.D.; Nieuwenhuijsen, M.J.; Wellenius, G.A.; Tonne, C. Performance of low-cost monitors to assess household air pollution. Environ. Res. 2018, 163, 53-63. [CrossRef] [PubMed]

26. Silva, L.F.O.; Pinto, D.; Neckel, A.; Oliveira, M.L.; Sampaio, C.H. Atmospheric nanocompounds on Lanzarote Island: Vehicular exhaust and igneous geologic formation interactions. Chemosphere 2020, 254, 126822. [CrossRef] [PubMed]

27. Silva, L.F.O.; Pinto, D.; Neckel, A.; Oliveira, M.L.S. An analysis of vehicular exhaust derived nanoparticles and historical Belgium fortress building interfaces. Geosci. Front. 2020, 11, 2053-2060. [CrossRef]

28. dos Reis, G.S.; Cazacliu, B.G.; Cothenet, A.; Poullain, P.; Wilhelm, M.; Sampaio, C.H.; Lima, E.C.; Ambrós, W.; Torrenti, J.-M. Fabrication, microstructure, and properties of fired clay bricks using construction and demolition waste sludge as the main additive. J. Clean. Prod. 2020, 258, 120733. [CrossRef]

29. Oliveira, M.L.S.; Neckel, A.; Pinto, D.; Maculan, L.S.; Dotto, G.L.; Silva, L.F.O. The impact of air pollutants on the degradation of two historic buildings in Bordeaux, France. Urban Clim. 2021, 39, 100927. [CrossRef]

30. Li, P.; Li, L.; Yang, K.; Zheng, T.; Liu, J.; Wang, Y. Characteristics of microbial aerosol particles dispersed downwind from rural sanitation facilities: Size distribution, source tracking and exposure risk. Environ. Res. 2021, 195, 110798. [CrossRef]

31. Li, T.-Y.; Xie, M.-Y.; Bao, L.-J.; Wu, C.-C.; Zeng, E.Y. Emissions of polycyclic aromatic hydrocarbons from primitive e-waste recycling: Particle size dependence and potential health risk. Sci. Total Environ. 2021, 781, 146814. [CrossRef]

32. Zhang, Y.; Guo, Z.; Peng, C.; Deng, H.; Xiao, X. A questionnaire based probabilistic risk assessment (PRA) of heavy metals in urban and suburban soils under different land uses and receptor populations. Sci. Total Environ. 2021, 793, 148525. [CrossRef]

33. Shao, L.; Ge, S.; Jones, T.; Santosh, M.; Silva, L.F.O.; Cao, Y.; Oliveira, M.L.S.; Zhang, M.; Bérubé, K. The role of airborne particles and environmental considerations in the transmission of SARS-CoV-2. Geosci. Front. 2021, 12, 101189. [CrossRef]

34. Toscan, P.C.; Neckel, A.; Maculan, L.S.; Korcelski, C.; Oliveira, M.L.S.; Bodah, E.T.; Bodah, B.W.; Kujawa, H.A.; Gonçalves, A.C. Use of Geospatial Tools to Predict the Risk of Contamination by SARS-CoV-2 in Urban Cemeteries. Available online: https://www.sciencedirect.com/science/article/pii/S1674987121001742 (accessed on 18 April 2021).

35. Zorzi, C.G.C.; Neckel, A.; Maculan, L.S.; Cardoso, G.T.; Dal Moro, L.; Del Savio, A.A.; Carrasco, L.D.Z.; Oliveira, M.L.S.; Bodah, E.T.; Bodah, B.W. Geo-Environmental Parametric 3D Models of SARS-CoV-2 Virus Circulation in Hospital Ventilation Systems. Available online: https://www.sciencedirect.com/science/article/pii/S1674987121001432 (accessed on 18 April 2021).

36. Morillas, H.; García-Florentino, C.; Marcaida, I.; Maguregui, M.; Arana, G.; Silva, L.F.O.; Madariaga, J.M. In-situ analytical study of bricks exposed to marine environment using hand-held X-ray fluorescence spectrometry and related laboratory techniques. Spectrochim. Acta Part B At. Spectrosc. 2018, 146, 28-35. [CrossRef] 
37. Morillas, H.; Vazquez, P.; Maguregui, M.; Marcaida, I.; Silva, L.F.O. Composition and porosity study of original and restoration materials included in a coastal historical construction. Constr. Build. Mater. 2018, 178, 384-392. [CrossRef]

38. Morillas, H.; Maguregui, M.; Gallego-Cartagena, E.; Huallparimachi, G.; Marcaida, I.; Salcedo, I.; Silva, L.F.O.; Astete, F. Evaluation of the role of biocolonizations in the conservation state of Machu Picchu (Peru): The Sacred Rock. Sci. Total Environ. 2019, 654, 1379-1388. [CrossRef] [PubMed]

39. Henriques, M. Will COVID-19 Have a Lasting Impact on The Environment? BBC Future: New York, NY, USA, 2020.

40. Tong, R.; Cheng, M.; Zhang, L.; Liu, M.; Yang, X.; Li, X.; Yin, W. The construction dust-induced occupational health risk using Monte-Carlo simulation. J. Clean. Prod. 2018, 184, 598-608. [CrossRef]

41. Cheriyan, D.; Choi, J.-H. Estimation of particulate matter exposure to construction workers using low-cost dust sensors. Sustain. Cities Soc. 2020, 59, 102197. [CrossRef]

42. Silva, L.F.O.; Milanes, C.; Pinto, D.; Ramirez, O.; Lima, B.D. Multiple hazardous elements in nanoparticulate matter from a Caribbean industrialized atmosphere. Chemosphere 2020, 239, 124776. [CrossRef] [PubMed]

43. Civeira, M.; Oliveira, M.; Hower, J.; Agudelo-Castañeda, D.; Taffarel, S.; Ramos, C.; Kautzmann, R.; Silva, L.F. Modification, adsorption, and geochemistry processes on altered minerals and amorphous phases on the nanometer scale: Examples from copper mining refuse, Touro, Spain. Environ. Sci. Pollut. Res. 2015, 23, 6535-6545. [CrossRef]

44. Civeira, M.S.; Ramos, C.G.; Oliveira, M.L.S.; Kautzmann, R.M.; Taffarel, S.R.; Teixeira, E.C.; Silva, L.F. Nano-mineralogy of suspended sediment during the beginning of coal rejects spill. Chemosphere 2016, 145, 142-147. [CrossRef] [PubMed]

45. Dalmora, A.C.; Ramos, C.G.; Querol, X.; Kautzmann, R.M.; Oliveira, M.L.S.; Taffarel, S.R.; Moreno, T.; Silva, L.F. Nanoparticulate mineral matter from basalt dust wastes. Chemosphere 2016, 144, 2013-2017. [CrossRef]

46. León-Mejía, G.; Silva, L.F.O.; Civeira, M.S.; Oliveira, M.; Machado, M.; Villela, I.V.; Hartmann, A.; Premoli, S.; Corrêa, D.S.; da Silva, J.; et al. Cytotoxicity and genotoxicity induced by coal and coal fly ash particles samples in V79 cells. Environ. Sci. Pollut. Res. 2016, 23, 24019-24031. [CrossRef]

47. Sehn, J.; De Leão, F.; Da Boit, K.; Oliveira, M.; Hidalgo, G.; Sampaio, C.; Silva, L.F. Nanomineralogy in the real world: A perspective on nanoparticles in the environmental impacts of coal fire. Chemosphere 2016, 147, 439-443. [CrossRef]

48. Rodriguez-Iruretagoiena, A.; de Vallejuelo, S.; de Diego, A.; de Leão, F.; de Medeiros, D.; Oliveira, M.; Tafarel, S.; Arana, G.; Madariaga, J.; Silva, L.F. The mobilization of hazardous elements after a tropical storm event in a polluted estuary. Sci. Total Environ. 2016, 565, 721-729. [CrossRef]

49. Ramos, C.G.; Querol, X.; Dalmora, A.C.; de Pires, K.C.J.; Schneider, I.A.H.; Oliveira, L.F.S.; Kautzmann, R.M. Evaluation of the potential of volcanic rock waste from southern Brazil as a natural soil fertilizer. J. Clean. Prod. 2017, 142, 2700-2706. [CrossRef]

50. Gasparotto, J.; Chaves, P.R.; Martinello, K.D.B.; da Rosa-Siva, H.T.; Bortolin, R.C.; Silva, L.F.O.; Rabelo, T.K.; da Silva, J.; da Silva, F.R.; Nordin, A.P.; et al. Obese rats are more vulnerable to inflammation, genotoxicity and oxidative stress induced by coal dust inhalation than non-obese rats. Ecotoxicol. Environ. Saf. 2018, 165, 44-51. [CrossRef]

51. Rodriguez, A.; de Vallejuelo, S.F.-O.; Gredilla, A.; Ramos, C.G.; Oliveira, M.L.S.; Arana, G.; de Diego, A.; Madariaga, J.M.; Silva, L.F.O. Fate of hazardous elements in agricultural soils surrounding a coal power plant complex from Santa Catarina (Brazil). Sci. Total Environ. 2015, 508, 374-382. [CrossRef] [PubMed]

52. Ribeiro, J.; Daboit, K.; Flores, D.; Kronbauer, M.A.; Silva, L.F.O. Extensive FE-SEM/EDS, HR-TEM/EDS and ToF-SIMS studies of micron- to nano-particles in anthracite fly ash. Sci. Total Environ. 2013, 452, 98-107. [CrossRef] [PubMed]

53. Dias, C.L.; Oliveira, M.L.S.; Hower, J.C.; Taffarel, S.R.; Kautzmann, R.M.; Silva, L.F.O. Nanominerals and ultrafine particles from coal fires from Santa Catarina, South Brazil. Int. J. Coal Geol. 2014, 122, 50-60. [CrossRef]

54. Silva, L.F.O.; Izquierdo, M.; Querol, X.; Finkelman, R.B.; Oliveira, M.L.S.; Wollenschlager, M.; Towler, M.; Pérez-López, R.; Macias, F. Leaching of potential hazardous elements of coal cleaning rejects. Environ. Monit. Assess. 2010, 175, 109-126. [CrossRef]

55. Silva, L.F.O.; Pinto, D.; Dotto, G.L.; Hower, J.C. Nanomineralogy of evaporative precipitation of efflorescent compounds from coal mine drainage. Geosci. Front. 2020, 12, 101003. [CrossRef]

56. Cao, P.; Zhang, B. Research and implementation of suppression method of dust pollution environment in large-scale construction. Ekoloji 2019, 28, 2813-2823.

57. De Paoli, F.; Agudelo-Castañeda, D.M.; Teixeira, E.C.; Silva, L.F.O.; Kumar, P. Number concentrations and size distributions of nanoparticles during the use of hand tools in refurbishment activities. J. Nanoparticle Res. 2018, 20, 264. [CrossRef]

58. Yang, C.; Liu, Y.; Sun, X.; Zhang, Y.; Hou, L.; Zhang, Q.; Yuan, C. In-situ construction of hierarchical accordion-like TiO2/Ti3C2 nanohybrid as anode material for lithium and sodium ion batteries. Electrochim. Acta 2018, 271, 165-172. [CrossRef]

59. Yu, Y.; Liu, S.; Wang, W.; Shang, Q.; Han, J.; Liu, C.; Tian, Z.; Chen, J. Eco-friendly utilization of sawdust: Ionic liquid-modified biochar for enhanced $\mathrm{Li}+$ storage of TiO2. Sci. Total Environ. 2021, 794, 148688. [CrossRef] [PubMed] 